\title{
Randomised trial of ganciclovir and acyclovir in the treatment of herpes simplex dendritic keratitis: a multicentre study
}

\author{
H B Hoh, C Hurley , C Claoue, M Viswalingham, D L Easty, P Goldschmidt, \\ L M T Collum
}

\begin{abstract}
Aims-This study was designed to assess the relative efficacy of topical ganciclovir $0.15 \%$ gel and acyclovir $3 \%$ ointment in the treatment of herpes simplex dendritic keratitis.

Methods-Both treatment modalities were administered on a five times daily basis to patients suffering from herpes simplex keratitis. Patients were assigned randomly to one of the two treatment groups for the purpose of the trial. They were then examined on days $2,7,10$, and 14 to assess the rate of healing of the dendritic ulceration.

Results-There was no statistically significant difference detected in the rate of healing between the two treatment groups over the course of the trial.

Conclusions-Review of the relative efficacy of topical ganciclovir and acyclovir in the treatment of herpes simplex dendritic keratitis showed that both treatment modalities were equally effective in their ability to heal the viral induced corneal ulceration. There were no significant side effects or adverse effects reported for either treatment modality.

(Br F Ophthalmol 1996; 80: 140-143)
\end{abstract}

The treatment of herpes simplex dendritic keratitis consists of mechanical debridement ${ }^{1}$ or the use of topical antivirals such as idoxuridine (IDU), ${ }^{2}$ bromovinyldeoxyuridine (BVDU), ${ }^{3}$ trifluorothymidine (F3T), ${ }^{4}$ adenine arabinoside (Ara-A), ${ }^{56}$ and acyclovir (ACV). ${ }^{78}$ More recent studies have shown success in the treatment of herpes simplex keratitis, using immunoglobulins ${ }^{9}$ and a combination of F3T and interferon- $\alpha{ }^{10}$ The choice of drug depends on its effectiveness against the virus and the toxic effects on the host. Most of these drugs have been shown to have some toxicity, such as follicular conjunctivitis, epithelial erosions, and punctal occlusion. ${ }^{11} 12$

In Europe, acyclovir remains the drug of choice in the treatment of herpes simplex dendritic keratitis owing to low levels of toxicity and its virostatic effect on herpes simplex virus. ${ }^{13} 14$ It blocks viral replication by the inhibition of viral DNA polymerase following phosphorylation by viral thymidine kinase, thus exhibiting selective activity towards virus infected cells. ${ }^{15-17}$ It is also better tolerated than the first generation of antiviral agents, such as IDU and F3T. ${ }^{18} 19$ Previous studies have also shown it to be at least as good as adenine arabinoside, ${ }^{6}$ with regard to rate of healing and resolution of symptoms. However, in its formulation as an ointment, it contains Vaseline which causes a degree of discomfort and visual impairment. This can be a problem particularly in patients with tear film disease. ${ }^{20}$ Acyclovir, taken in oral form, has also been shown to be effective in the treatment of herpes simplex keratitis. ${ }^{21}$

The need to have a similar efficient and nontoxic antiviral treatment is important following reports of the emergence of acyclovir resistant strains of herpes simplex virus both in vitro and in vivo. $22-24$

The active substance of GV 550 antiviral ophthalmic gel is ganciclovir or 9-(1,3-dihydroxy-2-propoxymethyl) guanine (DHPG), an acyclic nucleoside analogue structurally related to acyclovir, which is a potent inhibitor of herpes simplex virus replication. ${ }^{1625}$ Both compounds are activated by virus specific thymidine kinase which catalyses its phosphorylation into their active forms by cellular kinases. The phosphorylated form interferes with viral DNA polymerase activity and inhibits further viral DNA synthesis. In addition to its activity against herpes simplex virus, ${ }^{26}$ the drug has antiviral activity against adenovirus, ${ }^{27}$ Epstein-Barr virus, ${ }^{28} 2930$ and herpes zoster, ${ }^{31}$ and is currently in use for the systemic treatment of cytomegalovirus infection in immunocompromised patients. ${ }^{27} 32$

The effective median dose (ED50) of ganciclovir in vitro against clinical ocular isolates of herpes simplex virus is $0.23 \mu \mathrm{g} / \mathrm{ml}$ (range $0.06-0.5 \mu \mathrm{g} / \mathrm{l}$ ). Its efficacy, tolerance, and intraocular penetration have been demonstrated in experimental herpes simplex keratitis in rabbits. ${ }^{33-35}$ To date there have been no randomised clinical trials comparing it with antiviral agents currently in use against herpes simplex.

This prospective clinical trial was performed to evaluate the efficacy of GV 550 ophthalmic gel $0 \cdot 15 \%$ and acyclovir 3\% ophthalmic ointment (ACV) in the treatment of herpes simplex dendritic keratitis.

\section{Methodology}

Forty six patients with dendritic corneal ulceration of less than 7 days' duration were included in the study. Ethical approval by the local ethics committees was obtained before the trial was undertaken in each of the respective centres. Informed consent to participation 
Table 1 Demographic characteristics of patients in the two treatment groups

\begin{tabular}{lll}
\hline & $\begin{array}{l}\text { Ganciclovir 0.15\% } \\
(n=24)\end{array}$ & $\begin{array}{l}\text { Acyclovir 3\% } \\
(n=22)\end{array}$ \\
\hline Males & 20 & 13 \\
Females & 4 & 9 \\
Mean age (years) & $43 \cdot 5$ & 53 \\
Age range (years) & $24-68$ & $33-83$ \\
\hline
\end{tabular}

The patients within the ganciclovir treatment group were younger. Using the two sample $t$ test this was shown to be statistically significant $(\mathrm{p}=0 \cdot 0272)$.

in the trial was obtained and all patients were required to be over 18 years of age. We excluded patients who were hypersensitive to either ganciclovir or acyclovir, those who had had immunosuppressive, antiviral, or steroid therapy in the preceding 14 days, those who had stromal corneal involvement or keratouveitis, and females of child bearing age. In addition, the visual acuity of the contralateral eye had to be $6 / 36$ or better.

These patients were then randomised to either GV 550 or ACV, used five times daily until the ulcer healed and then three times daily for a further 3 days. They were examined on the $2 \mathrm{nd}, 7 \mathrm{th}, 10 \mathrm{th}$, and 14 th days after the initial consultation. The visual acuity, symptoms and signs including the size of the ulcer were assessed. Symptoms of lacrimation, grittiness, photophobia, blurred vision, pain, and itchiness were scored on a 1-3 scale (mild/moderate/severe). Evidence of conjunctival (bulbar and palpebral), hyperaemia, papillary or follicular reaction, fluorescein conjunctival staining, and the presence of a Tyndall reaction was similarly scored. The size of the ulcer was measured as the greatest length in millimetres when stained with fluorescein. Healing was deemed to have been achieved when there was no fluorescein uptake.

Patients were withdrawn if there was no improvement or worsening of the ulcer on day 5 , if the dendritic ulcer had not healed by day 14 , if a fresh ulcer appeared, if the ulceration

Table 2 Symptoms and signs scoring by the two treatment groups

\begin{tabular}{|c|c|c|c|c|c|}
\hline & \multicolumn{5}{|l|}{ Day } \\
\hline & 0 & 2 & 7 & 10 & 14 \\
\hline \multicolumn{6}{|l|}{ Signs: } \\
\hline $\begin{array}{l}\text { Ganciclovir } \\
\text { Acyclovir } \\
\text { p Values }\end{array}$ & $\begin{array}{l}5 \cdot 29 \\
4 \cdot 59 \\
0 \cdot 4206\end{array}$ & $\begin{array}{l}3 \cdot 12 \\
3 \cdot 31 \\
0 \cdot 7723\end{array}$ & $\begin{array}{l}1.66 \\
1.66 \\
1.0000\end{array}$ & $\begin{array}{l}0 \cdot 83 \\
0.89 \\
0.8104\end{array}$ & $\begin{array}{l}0.20 \\
0 \cdot 57 \\
0 \cdot 1933\end{array}$ \\
\hline \multicolumn{6}{|l|}{ Symptoms: } \\
\hline $\begin{array}{l}\text { Ganciclovir } \\
\text { Acyclovir } \\
\text { p Values }\end{array}$ & $\begin{array}{l}9.08 \\
9.95 \\
0.7566\end{array}$ & $\begin{array}{l}4 \cdot 04 \\
5 \cdot 29 \\
0 \cdot 2075\end{array}$ & $\begin{array}{l}1 \cdot 50 \\
4 \cdot 00 \\
0 \cdot 0055\end{array}$ & $\begin{array}{l}1 \cdot 12 \\
1.78 \\
0 \cdot 2361\end{array}$ & $\begin{array}{l}0.54 \\
0.1042\end{array}$ \\
\hline
\end{tabular}

All the $\mathrm{p}$ values in the above table were calculated using the two sample $t$ test.

Table 3 Mean dendritic ulcer sizes ( $\mathrm{mm}$ ) in the two treatment groups

\begin{tabular}{llllll}
\hline & Day & & & \\
\cline { 2 - 6 } & 0 & 2 & 7 & 10 & 14 \\
\hline Ganciclovir $(\mathrm{n}=24)$ & $3 \cdot 26$ & 1.39 & $0 \cdot 1$ & $0 \cdot 14$ & All healed \\
Acyclovir $(\mathrm{n}=22)$ & $3 \cdot 12$ & 1.34 & 0.59 & 0.24 & $0 \cdot 15$ \\
p Values & 0.8387 & 0.6804 & 0.1902 & 0.7676 & 0.3322 \\
\hline
\end{tabular}

Two patients were withdrawn from the ganciclovir group for reasons outlined in the result sequence in the text. Three patients in the acyclovir group were lost to follow up in the course of the trial (see text above). recurred, or if there was anterior chamber or stromal involvement. They were also withdrawn if drug toxicity was noted. Evidence of drug toxicity was recorded at each visit. The effects of the drug on vision and the duration of this disturbance were documented.

This trial could not be made double masked owing to the obvious difference in the appearance between the gel and ointment formulations of the two drugs. Statistical analyses were performed using the two sample $t$ test.

\section{Results}

The overall number of patients enrolled were as follows: 24 patients in the GV 550 group (20 males/four females) and 22 patients in the acyclovir group (13 males/nine females). Within the GV 550 treatment group, the mean age was 43.5 years, while the ACV treatment group had a mean age of 53 years. The patients within the GV 550 treatment group were younger $(p=0.0272)$. The demographic characteristics of the patients enrolled in the trial are shown in Table 1. Two patients from the GV 550 group were withdrawn during the course of the trial. One patient was withdrawn at day 10 as the ulcer had not healed, and the second was withdrawn at day 14 owing to the development of a fresh dendritic ulcer while the patient was still being treated. Three patients in the acyclovir group were lost to follow up, at days 2,7 , and 10 respectively.

On presentation, the mean ulcer length was $3.26 \mathrm{~mm}$ in the GV 550 group and $3.12 \mathrm{~mm}$ in the ACV group respectively. This was not statistically significant $(p=0 \cdot 8387)$. The symptoms and signs were comparable between the two groups (Table 2).

On review over the next 14 days, there was improvement in the scoring of symptoms and signs in both treatment groups (Table 2). There was a steady decrease in the mean size of the dendritic ulcers, with treatment and complete healing achieved by day 14 in all the patients in the GV 550 group other than the two patients withdrawn on days 10 and 14 (see above) and in all but two patients in the acyclovir group (Table 3). At day 2 of follow up, the mean ulcer size in the ACV treatment group was 1.34 (SD 1.58) mm, compared with $1.39(1.71) \mathrm{mm}$ in the GV 550 group, while at day 7 , the sizes were $0.59(1.1) \mathrm{mm}$ and 0.1 $(0 \cdot 42) \mathrm{mm}$, respectively. By day 10 the mean ulcer size in the acyclovir treatment groups was $0.24(0.78) \mathrm{mm}$, compared with 0.14 $(0 \cdot 45) \mathrm{mm}$ in the ganciclovir treated group. It is of note that the standard deviations exceeded the mean ulcer size. This was because of a wide range and some diverse values of the ulcer size in each of the treatment groups on the various days of the trial. By day 14 all the patients in the GV 550 group had healed other than the two withdrawn on days 10 and 14 (see above). Two patients in the acyclovir treated group were not completely healed, however, and the mean ulcer size at day 14 in the acyclovir treated group was $0 \cdot 15$ (SD 0.47$) \mathrm{mm}$. There was no statistically significant difference detected in the rate of 
Table 4 Comparison of side effects in the two treatment groups

\begin{tabular}{lcc}
\hline & Ganciclovir 0.15\% & Acyclovir 3\% \\
\hline Local toxic effects & $0 \%$ & $0 \%$ \\
Visual disturbance & $50 \%$ & $47 \cdot 8 \%$ \\
mild blurring & $29 \cdot 1 \%$ & $30 \cdot 4 \%$ \\
$\begin{array}{l}\text { moderate blurring } \\
\text { severe blurring }\end{array}$ & $4 \cdot 1 \%$ & $8 \cdot 6 \%$ \\
$\begin{array}{l}\text { Mean duration of visual } \\
\text { disturbance }\end{array}$ & 22 minutes & $32 \cdot 9$ minutes \\
Range of duration of & $0-240$ minutes & $0-300$ minutes \\
\hline
\end{tabular}

For the purposes of presentation, the duration of visual blurring was defined as mild (less than or equal to 10 minutes), moderate (greater than 10 but less than or equal to 60 moderate (greater than 10 but less than or equal to 60
minutes), or severe (any duration greater than 60 minutes).

healing between the two groups. The $p$ values for the difference in ulcer size between the two groups at each of the follow up days are shown in Table 3.

There was, however, some difference in the duration of blurring on application of the two drugs. When questioned at the end of the treatment period, $50 \%$ of patients using GV 550 gel reported mild to moderate blurring of vision after administration of the drug, $29 \cdot 1 \%$ reported moderate to severe blurring of vision, and $4 \cdot 1 \%$ reported severe blurring of vision. In the patients treated with ACV ophthalmic ointment, $47 \cdot 8 \%$ reported mild to moderate blurring of vision following administration of the drug, $30.4 \%$ reported moderate to severe blurring of vision, and $8.6 \%$ reported severe blurring of vision. Those using the gel formulated GV 550 reported the disturbance of vision to last an average of 22 minutes, compared with 32.9 minutes reported by the group using ACV ophthalmic ointment (Table 4). There were no adverse effects seen in either group during the treatment period.

\section{Discussion}

This study established that GV $5500 \cdot 15 \%$ gel heals herpes simplex dendritic ulcers as rapidly as ACV 3\% ointment. Both drugs are effective against herpes simplex virus types 1 and 2 by selective inhibition of viral coded DNA polymerase.

Studies on animal corneas demonstrated antiviral effects comparable with that of acyclovir 3\% ointment, with no toxic effects seen at $0.3 \%$ concentration. 3435

There were no differences between the cumulative healing rates and reduction in ulcer sizes between the patients using GV 550 and ACV. This is shown in Figure 1, where the percentage of patients in each treatment group, whose ulcer had not completely healed, is plotted against the review day of the trial. There were no serious complications associated with drug instillation in either treatment group. The only adverse effect was a temporary disturbance in vision on application of the drug in $83.2 \%$ of patients overall treated with GV 550 and in $86.8 \%$ of patients overall treated with acyclovir. More significantly, the duration of this effect was longer (mean duration of 32.9 minutes) in the ACV group compared with the GV 550 group (mean duration of 22 minutes). This effect is most probably

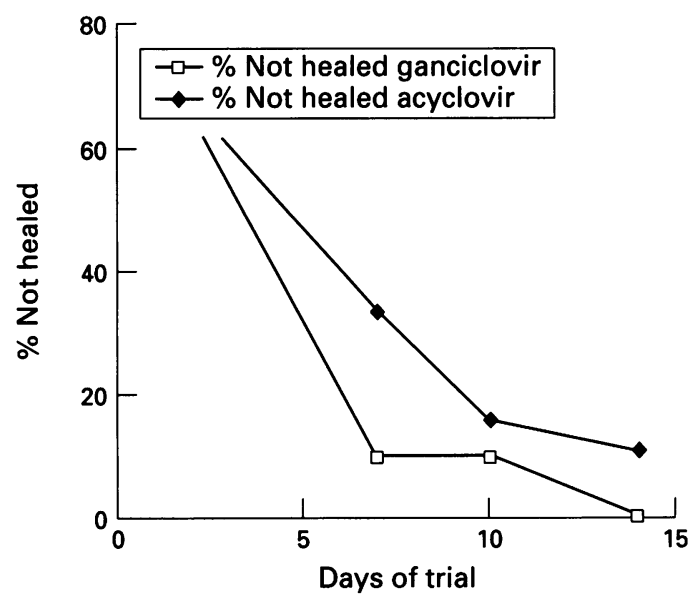

Figure 1 Cumulative frequency distribution of time taken to heal.

due to the hydrophilic nature of the carrying vehicle used in the formulation of GV 550 gel, the vehicle used in ACV ointment being of lipophilic nature.

Carbomer, the gel forming ingredient used in the manufacture of GV 550 is a synthetic, hydrophilic high molecular weight crosslinked polymer of acrylic acid. It has been shown to be safe when used as a topical preparation and is currently used as the carrying vehicle in tear substitutes because of its advantage of longer contact time. This aqueous carbomer gel based GV 550 allows adequate penetration of the drug with the additional advantage of less visual blurring during the treatment period.

We conclude that ganciclovir $0 \cdot 15 \%$ ophthalmic gel is an equally effective and safe alternative to acyclovir $3 \%$ ophthalmic ointment in the treatment of herpes simplex dendritic ulcers with the advantage of having less effect on blurring of vision owing to its water miscible property.

The authors are grateful to the casualty department at the Bristol Eye Hospital, in particular sister Jane Fox and charge nurse Tim Withers. They also acknowledge the outpatient staff nurse Tim Withers. They also acknowledge the outpatient staff Hospital, Dublin and the corneal department of Moorfields Eye Hospital, Dublin and the corneal department of Moorfields Eye Hospital, London. The authors are also grateful to Mr Paul
Kenna, Research Department, Royal Victoria Eye and Ear Hospital, Dublin for his assistance with the statistical analyses.

1 Coster DJ, Jones BR, Falcon MG. Role of debridement in the treatment of herpetic keratitis. Trans Ophthalmol So UK 1977; 97: 314-7.

2 Collum LMT, Benedict-Smith A, Hillary IB. Randomised double-blind trial of acyclovir and idoxuridine in dendritic corneal ulceration. Br 7 Ophthalmol 1980; 64: 766-9.

3 Power WJ, Benedict-Smith A, Hillery M, Brady K, Collum LMT. Bromovinyldeoxyuridine (BVDU) and trifluorothymidine (TFT) in dendtritic corneal ulceration: a double blind controlled study. Curr Eye Res 1991; 10: double

4 Laibson PR, Arentsen J, Mazzanti WD, Eiferman RA. Double controlled comparison of IDU and trifluorothymidine in thirty-three patients with superficial herpetic keratitis. Trans Am Ophthalmol Soc 1977; 75: 316-24.

5 McGill J, Tormey P, Walker CB. Comparative trial of acyclovir and adenine arabinoside in the treatment of herpes simplex corneal ulcers. Br $\mathcal{F}$ Ophthalmol 1981; 65: 610-3.

6 Collum LMT, Logan P, McAuliffe-Curtin D, Hung SO, Patterson A, Rees PJ. Randomised double blind trial of acyclovir and adenine arabinoside in herpes simplex 847-50.

7 Falcon MG, Jones BR. Antivirals for the therapy of herpetic eye disease. Trans Ophthalmol Soc UK 1977; 97: 330-2.

Kaufman HE. Update on antiviral agents. Ophthalmology 1985; 92: 533-6.

9 Klager AJ, Buchi ER, Osuky R, Burek-Kozlowska A, Morell A. Topical immunoglobulins for epithelial herpes simplex keratitis. Ophthalmologica 1993; 209: 78-81.

10 Birch CJ, Tyssen DP, Tachedjian G, Doherty R, Hayes K, 
Mijch A. Clinical effects and in vitro studies of trifluorothymidine combined with interferon-alpha for treatment of drug-resistant and sensitive herpes simplex virus infections. F Infect Dis 1992; 166: 108-12.

11 Wilson F. Adverse external ocular effects of topical ophthalmic medications. Surv Ophthalmol 1979; 24: 57-88.

12 Lass $\mathrm{JH}$, Thoft RA, Dohlman $\mathrm{CH}$. Idoxuridine-induced conjunctival cicatrization. Arch Ophthalmol 1983; 101: 747-50.

13 Collum LMT, Benedict-Smith A. Acyclovir (Zovirax) in herpes simplex keratitis. In: Sundmacher R, ed. Herpetic eye diseases. Munich: J F Bergmann Verlag, 323-7.

14 Elion GB, Furman PA, Fyfe JA, deMiranda P, Beauchamp L, Schaeffer HJ. Selectivity of action of an antiherpetic agent 9-(2-hydroxyethoxymethyl)-guanine. Proc Nat Acad Sci 1977; 74: 5716-20.

15 Furman PA, DeMiranda P, St Clair MH, Elion GB Metabolism of acyclovir in virus-infected and uninfected cells. Antimicrob Agents Chemother 1981; 20: 518-24.

16 Furman PA, St Clair MH, Fyfe JA, Rideout JL, Keller PM, Elion GB. Inhibition of herpes simplex virus-induced DNA polymerase activity and viral DNA replication by DNA polymerase activity and viral DNA replication by
9-(1,3-dihydroxy-2-propoxymethyl)-guanine and its 9-(1,3-dihydroxy-2-propoxymethyl)-
triphosphate. F Virol 1979; 32: 72-7.

17 Furman PA, St Clair MH, Spector T. Acyclovir triphosphate is a suicide inactivator of the herpes simplex virus DNA polymerase. F Biol Chem 1984; 259: 9575-9.

18 Colin J. Superficial herpes-simplex keratitis - a double-blind comparative trial of acyclovir and idoxuridine. Nouv Presse Med 1981; 10/36: 2969-75.

19 La Lau C, Oosterhuis J, Versteeg J, Van Rij G. Renardel De Lavalette JGC, Craandjik A. Acyclovir and trifluorothymidine in herpetic keratitis - a multicentre trial. $\mathrm{Br} \mathcal{F}$ thymidine in herpetic keratitis

20 Collum LMT, Power WJ, Collum A. The current management of herpetic eye disease. Doc Ophthalmol 1992; 80: 201-5.

21 Collum LMT, MacGettrick P, Akhtar J, Rees PJ. Oral acyclovir in herpetic keratitis. In: Maudgal PC, Missotten $\mathrm{L}$, eds. Herpetic eye diseases. Amsterdam: Dr W Junk, 1985: 233-40.

22 Schnipper LE, Crumpacker CS. Resistance of herpes simplex virus to acycloguanosine: role of viral thymidine kinase and DNA polymerase loci. Proc Natl Acad Sci USA 1980; 77: 2270-6.
23 Smith KO, Kennell WL, Poirier RH, Lynd FT. In vitro and in vivo resistance of herpes simplex virus to 9-(2-hydroxyethoxymethyl) guanine (acycloguanosine). Antimicrob Agents Chemother 1980; 17: 144-50.

24 Crumpacker CS, Schnipper LE, Marlowe SI, Kowalsky PN, Hershey BJ, Levin MJ. Resistance to antiviral drugs of herpes simplex virus isolated from a patient treated with acyclovir. N Engl ₹ Med 1982; 306: 343-6.

25 Matthews T, Boehme R. Antiviral activity and mechanism of action of ganciclovir. Rev Infect Dis 1988; 10: S490-4.

26 Smee DF, Campbell ML, Matthews TR. Comparative anti-herpes virus activities of 9-(1,3-dihydroxy-2propoxymethyl) guanine, acyclovir and two 2-fluoropyrimidine nucleosides. Antiviral Res 1985; 5: 259-67.

27 Taylor DD, Jeffries DJ, Taylor-Robinson D, Parkin JM, Tyms AS. The susceptibility of adenovirus infection to the anti-cytomegalovirus drug, ganciclovir (DHPG). FEMS Microbiol Lett 1988; 49: 337-41.

28 Ishida $Y$, Yokota Y, Tauchi H, Fukuda M, Takoaka T, Hayashi M. Ganciclovir for chronic active Epstein-Barr virus infection [Letter]. Lancet 1993; 341: 560-1.

29 Oettle H, Wilborn F, Schmidt CA, Siegert W. Treatment with ganciclovir and Ig for acute Epstein-Barr virus infection after allogenetic bone marrow transplantation [Letter]. Blood 1993; 82: 2257-8.

30 Yao GQ, Grill S, Egan W, Cheng YC. Potent inhibition of Epstein-Barr virus by phosphorothioate oligo deoxynucleotides without sequence specification. Antimicrob Agents Chemother 1993; 37: 1420-5.

31 Poscher ME. Successful treatment of varicella zoster virus meningoencephalitis in patients with AIDS; report of four cases and review. AIDS 1994; 8: 1115-7.

32 Marka A Fulds D Ganciclovir in update of its therapeutic use in cytomegalovirus infection. Drugs 1994; 48: 455-84.

33 Smith KO, Hodges SL, Kennell WL, Galloway KS, Poirier $\mathrm{RH}$, Ogilvie KK, et al. Experimental ocular herpetic infections in rabbits. Arch Ophthalmol 1984; 102: 778-81.

34 Shiota $H$, Naito $T$, Mimura $Y$. Anti-herpes simplex virus effect of 9-(1,3-dihydroxy-2-propoxymethyl) guanine in rabbit cornea. Curr Eye Res 1987; 6: 241-5.

35 Trousdale MD, Nesburn AB, Willey DE, Taiid H. Efficacy of BW759 9-(1,3-dihydroxy-2-propoxymethyl) guanine Curr Eye Res 1984; 3: 1007-15. 